Management for the Public Domain 


\section{Management for the Public Domain}

Enabling the Learning Society

Stewart Ranson

and

John Stewart

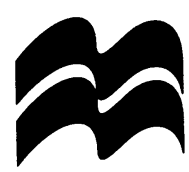




\section{(c) Stewart Ranson and John Stewart 1994}

All rights reserved. No reproduction, copy or transmission of this publication may be made without written permission.

No paragraph of this publication may be reproduced, copied or transmitted save with written permission or in accordance with the provisions of the Copyright, Designs and Patents Act 1988, or under the terms of any licence permitting limited copying issued by the Copyright Licensing Agency, 90 Tottenham Court Road, London WIP 9HE.

Any person who does any unauthorised act in relation to this publication may be liable to criminal prosecution and civil claims for damages.

First published in Great Britain 1994 by

THE MACMILLAN PRESS LTD

Houndmills, Basingstoke, Hampshire RG21 2XS

and London

Companies and representatives

throughout the world

A catalogue record for this book is available

from the British Library.

ISBN 978-0-333-49558-2 ISBN 978-1-349-23787-6 (eBook)

DOI 10.1007/978-1-349-23787-6

$\begin{array}{rrrrrrrrr}10 & 9 & 8 & 7 & 6 & 5 & 4 & 3 & 2 \\ 04 & 03 & 02 & 01 & 00 & 99 & 98 & 97 & 96\end{array}$

First published in the United States of America 1994 by

Scholarly and Reference Division,

ST. MARTIN'S PRESS, INC.,

175 Fifth Avenue,

New York, N.Y. 10010

ISBN 978-0-312-12284-3

Library of Congress Cataloging-in-Publication Data

Ranson, Stewart.

Management for the public domain : enabling the learning society /

Stewart Ranson and John Stewart.

p. $\mathrm{cm}$.

Includes bibliographical references and index.

ISBN 978-0-312-12284-3

1. Public administration. 2. Management. I. Stewart, John

David, 1929- . II. Title.

JF1351.R285 1994

$350^{\prime} .0001-\mathrm{dc} 20$ 


\section{Contents}

List of Exhibits

viii

Preface

\section{PART I PUBLIC ORGANISATIONS IN QUESTION}

1 Transformations and Predicaments 3

The beleaguered public sector $\quad 3$

The transformations 6

The New Right and the challenge of consumerism 13

$\begin{array}{ll}\text { The dilemmas of public service } & 17\end{array}$

Conclusion $\quad 22$

2 Towards a Theory of Public Management 25

Rediscovering public management $\quad 25$

The need for theory $\quad 29$

Conceptualising management $\quad 32$

Explaining the variety of management systems $\quad 37$

Constituting systems of management: the social and political order $\quad 40$

A typology of management $\quad 45$

Conclusion $\quad 49$

\section{PART II THE PUBLIC DOMAIN: PURPOSES AND CONDITIONS}

3 The Dualities of Citizenship 53

The distinctive purposes of the public domain 54

The distinctive values of the public domain $\quad 62$

For citizenship in the public domain $\quad 70$

$\begin{array}{ll}\text { The learning society } & 77\end{array}$

$\begin{array}{lr}\text { Conclusion } & 86\end{array}$ 
4 Organising Principles

An unbounded area of public concern $\quad 88$

Public discourse

Consent through accountablility $\quad 93$

Political process and collective choice $\quad 94$

Political process as the condition for public management

The requirements of management in the public domain

Summary

5 Renewing Democracy

Institutional conditions

Constitutive systems: democracy and government

Empowering the citizen

Conclusion: towards community governance

6 Interdependence and Cooperation

The network of organisation

The necessities of inter-organisational working

A presumption of competition or of cooperation

The need for system management

The requirements of system management and of inter-organisational management

Conclusion

\section{PART III THE CHANGING TASKS OF PUBLIC MANAGEMENT}

7 Beyond Codes and Contracts

The codes of public management under social democracy

Building the conditions for effective public management

Public management as contracted responsibilities

The special case of contracting

Conclusion: Developing public management for learning 
8 Public Learning $\quad 168$

Theory of learning and organisational learning $\quad 168$

The organisational conditions for public learning $\quad 175$

The management of learning $\quad 180$

$\begin{array}{lr}\text { Conclusion } & 186\end{array}$

9 Judging Public Choice 187

The necessity of judgement $\quad 187$

The contribution of strategic management $\quad 189$

The phases of strategic management 193

Conclusion $\quad 220$

10 Enabling Public Accountability 221

Accounting for performance 221

The development of performance review for public accountability 223

The necessary limits on performance measurement in the public domain 226

Judgement, not measurement 231

Rediscovering public accountability 233

Accountability for citizenship in a learning society $\quad 235$

Conclusion $\quad 241$

11 Empowering a Public Culture 242

Challenging the dominance of organisational
continuity

Towards a public culture $\quad 244$

Designing the public organisation 253

Staffing for citizenship 258

Dilemmas faced $\quad 265$

Conclusion $\quad 268$

Conclusion $\quad 269$

The challenge for the public management 269

The nature of public management $\quad 270$

$\begin{array}{ll}\text { References } & 274\end{array}$

$\begin{array}{ll}\text { Index } & 292\end{array}$ 


\section{List of Exhibits}

5,1 Consensual approaches to environmental issues

5.2 A citizen panel

6.1 Planned markets in Scandinavian health services

6.2 A failure in system management

7.1 The Financial Management Initiative

8.1 The development of local purchasing

8.2 Searching out voices not always heard

8.3 Attitudes to policing

9.1 Strategic issues in the health service

9.2 Food policy issues on the agenda

9.3 The fat-intake issue or a conflict of interest

9.4 The location of magistrates' courts

10.1 Sentencing in magistrates' courts

11.1 Equal opportunities

11.2 The Benefits Agency programme - Towards the Core Values 


\section{Preface}

This book has its origins in two articles that we wrote in 1988 of which the first published bore a similar title to this book 'Management in the Public Domain'. We argued in those articles that analysis of management in the public domain had been conditioned, consciously or unconsciously, by the nature of management in the private sector. Even where differences were recognised, writings on management in the public sector conceptualised it negatively as 'non-market' or 'not-for-profit management', rather than positively as, for example, 'public service management'. Such an approach limited understanding, leading to neglect of the distinctive purposes, conditions and tasks of what we described as the public domain, meaning by that phrase to describe a sphere of activities in which distinctive values are realised and which is governed by its own organising principles.

We showed in the first article (Stewart and Ranson, 1988) that the result of the dominance of the private sector model led either to the neglect of aspects of management that were of importance in the public domain or to a distorted treatment of other aspects. One illustration of neglect was the tendency to ignore the political process which governs activity in the public domain or to treat it as an obstacle to effective management, whereas we argued that management in the public domain should rather be designed to support and express the political processes that govern that domain. An illustration of the distortion that could result from inappropriate application of the private sector model was the introduction of marketing approaches which treated the public solely as customer, ignoring the public as citizen and the reality that many services in the public domain are rationed according to criteria of need rather than supplied according to demand at a given price. 


\section{$\mathrm{x}$ Preface}

We argued that the private sector model has a different basis from the model of management in the public domain.

Our argument was not that particular approaches could not be developed for the public domain from the private sector. Both can learn particular approaches from each other. Rather our argument was for the development of ways of thinking about management in the public domain which were grounded in the distinctive purposes, conditions and tasks of that domain. There was a need for an analysis of management that was as rigorous as any developed for the private sector, but one which took public purposes, conditions and tasks as its starting point. Approaches to management could be developed from such analysis that could support rather than deny the nature of the public domain.

Since we wrote those articles there has been the development in many countries of what has been called the new public management, which is based to a very large extent upon the private sector model, stressing as it does the use of market mechanisms and competition, and the idea of the public as customer. The development of the new public management has led to the growth of a literature appraising its development. In that literature are to be found both advocates and critics of the development, but whichever stance is taken the starting point is the new public management, rather than the search for an approach to management grounded in the purposes, conditions and tasks of the public domain. The need identified in our article for the development of such an approach has been made more urgent by the advance of the new public management.

It is that task that we have undertaken in this book. It sets out to reconceptualise public management based upon an understanding of its distinctive purposes, conditions and tasks. It is not therefore another textbook on public sector management, but a book that sets out a perspective on public sector management which describes not what is, but points the way to what could be. We hope it will guide both students and practitioners in their thinking. From that perspective can develop, as we show, approaches to management which can strengthen the public domain. From that perspective developments in the new public management can be appraised not on their own terms, but on terms set by a new understanding of the nature of the public domain. 
This perspective on public management has grown out of a critical analysis of the social, economic and political changes in the UK since the early 1970s. These changes have suggested that the 'settlement' between the classes after the Second World War to create a more just society was withering away and with it the authority of the polity. Accelerating unemployment together with the fragmenting of communities has often eroded the sense of membership of and participation in the public life of the community. This is particularly disturbing when these and other changes - for example environmental erosion - present problems whose resolution requires by definition collective action informed by some sense of the public good for the community as a whole. It is the principal purpose of the public domain to develop those institutions and values which enable citizens to flourish not only as individuals but also in their contribution to the life and wellbeing of society. The failure of the polity in this period is to have abandoned this understanding of its purpose, not least because its own legitimacy and thus survival depend upon the authority it derives from public consent. The challenge for the public domain and its management is to rediscover the foundations of democratic citizenship that alone can regenerate the quality of life for the public as a whole.

While the structure of this argument derives from particular experience it leads to a general analysis of wide applicability. The impact upon society of the interaction of the "post-industrial revolution' and neo-liberal policies which emphasise the individual above society has been experienced in many countries. But this historical juncture should also be taken to illustrate what has been neglected and taken for granted, namely that any society at any time can really only flourish with a public domain that strives to hold in balance the necessary relationship between the private and the public good.

The case study from which we have developed our argument is intended to contribute to a wider international debate about public management.

The argument of the book unfolds in three stages. In Part I we discuss the scope of the public domain, the activities that are governed by it and how the ways of working developed therein have varied over time. We have set out the dominant trends in the 
postwar period, placing emphasis upon the social democratic polity of the immediate postwar period and on the neo-liberal polity of recent years. We show that both in their different ways gave expression to a restricted concept of the public domain which conditioned the nature of management, limiting its role. We argue that the conditions of our time need a concept of the public domain that realises its full potential, because it must support a learning society committed to the development of communities and individuals. The book aims to show what that renewal of the public domain means for management, whose role would then be to enable the learning society. In this part of the book we draw upon management theory, showing how different management categories which may provide a common framework for analysis are given different meanings by the purposes, conditions and tasks of particular organisational contexts. There is no generic approach to management; that is why it is necessary to explore the distinctive nature of the management of the public domain in the context of the learning society.

Part II explores the nature of the public domain. Because the learning society requires the development of its full potential, this part explores its values, which leads to an examination of the nature of citizenship that is realised in that domain. It is then argued that the distinctive organising principles of the public domain are based upon public discourse leading to collective choice based on public consent. Those principles can best be realised through institutional reform directed at a renewal of democracy. Those reformed institutions should realise their mutual interdependence, resting as they do on a presumption of cooperation, derived from the organising principle by which all should be governed.

Part III explores how management can meet the distinctive purposes and conditions of the public domain derived from its organising principles. In this way management can enable the learning society. This part argues that this needs approaches which permit an enhanced capacity for change and development in public organisations. The nature of those approaches is explored in chapters that examine how management can enable organisational tasks of sustaining public learning, supporting public choice and public accountability, and empowering a public culture. In these chapters therefore the nature of management in 
the public domain is discussed. These approaches both support and draw upon public discourse and the political processes through which it can be expressed. In exploring the implications new directions can be found for management. The book presents therefore alternatives to both past and prevalent approaches which have too often ignored the necessity of public discourse and of effective political processes for the vitality of the public domain and for its management.

The book concludes with a recognition that management in the public domain has to support and express political judgement, since that judgement tested in public discourse underlies the organisational tasks discussed in Part III. Judgement sustains the learning society and management in the public domain should sustain judgement.

The sources of our interest and concern with management in the public domain are: our continuing work in teaching and research for and in that domain, the many practitioners with whom we have discussed the deep issues all confront in managing in that domain, and our colleagues in the Schools of Education and Public Policy who have challenged our thinking. We are especially grateful to the Local Government Training Board (now the Local Government Management Board) who first gave us the opportunity to reflect on this theme and to Steven Kennedy for his support and considerable patience. We would also like to thank Kathy Bonehill and Jenny Neave for their excellent secretarial support.

The book draws upon ideas and material from various articles and books we have written. In particular it draws upon:

Stewart, J. and S. Ranson (1988) 'Management in the Public Domain', Public Money and Management, 8 (1/2), pp. 13-19. Ranson, S. and J. Stewart (1989) 'Citizenship and Government:

The Challenge for Management in the Public Domain', Political Science, 37 (1), pp. 5-24.

Ranson, S. (1992) 'Towards the Learning Society', Education Management and Administration 20 (2), pp. 68-79.

Stewart, J. and K. Walsh (1992) 'Change in the Management of Public Services', Public Administration.

Ranson, S. (1993) 'Markets or Democracy for Education', British Journal of Educational Studies, 42 (4), pp. 332-52. 
xiv Preface

Ranson, S. (1994) Towards the Learning Society (London: Cassell). Stewart, J. and K. Walsh (1994) 'Performance Management When Performance Can Never be Finally Defined', Public Money and Management, forthcoming.

STEWART RANSON JOHN STEWART 